\title{
Is tax shield really a function of net income, interest rate, debt and tax rate? Evidence from Slovak companies
}

\section{Tomas Kliestik}

Faculty of Operation and Economics of Transport and

Communications, University of Zilina,

Slovak Republic

tomas.kliestik@fpedas.uniza.sk

\section{Lucia Michalkova}

Faculty of Operation and Economics of Transport and

Communications, University of Zilina.

Slovak Republic

lucia.michalkova@fpedas.uniza.sk

\author{
Maria Kovacova \\ Faculty of Operation and Economics of Transport and \\ Communications, University of Zilina. \\ Slovak Republic \\ maria.kovacova@ppedas.uniza.sk
}

Abstract. Existence of tax shields as a result of taxable expenditures is a significant factor determining profitability and rentability of enterprises. In the long-term horizon, it represents a relevant and a significant generator of corporate value. The aim of the present paper is to propose, quantify and validate a comprehensive model to identify the determinants of the value of the interest tax shield in the conditions of Slovak Republic. The model was developed based on a multiple linear regression analysis, the conditions of multicollinearity of explaining variables, homoscedasticity, autocorrelation and normality of residuals were tested. Input data were obtained from the financial statements of the year 2017 of more than 6,000 Slovak companies. Using the proposed model, we found that the value of tax shield is lower than the product of the debt value and the tax rate, which is symptomatic for imperfect markets. Stemming from these results we can state that reclassification of Slovak economy considering the positive development of traditional macroeconomic indicators, using a simple comparative analysis in the context of dynamic development of the emerging markets, is not correct. Slovak economy has the status of the so-called emerging economy sui generis, which forms a platform to verify a wide range of economic mechanisms and functionalities with respect to the identified

Received:

May, 2018

1st Revision:

October, 2018

Accepted:

November, 2018

DOI:

$10.14254 / 2071$ $8330.2018 / 11-4 / 21$ 
particularity.

Keywords: tax shields, debt value, emerging economy, linear regression.

JEL Classification: G32, P34

\section{INTRODUCTION}

Maximizing enterprise profit is generally considered to be the main business objective (Strouhal et al., 2018; Batchimeg, 2017; Ključnikov et al., 2017). Businesses can meet that objective in two ways, which in most cases are interdependent: they can streamline their operating activities, or use various ways to reduce their tax liability in order to maximize the profit after tax. Reduction of tax liability may be illegal or legal. Legal way to reduce tax liability is called tax optimisation and it is part of the taxation policy of every company.

The existence of tax savings (tax shield) as a result of tax deductible expenses is an important factor in profitability of enterprises, in the long term it is also one of the determinants of the company's value. Tax shields are the objects of interest to business managers, but also for scientific community (for example, Šimková, 2015; Paseková et al., 2018). On the world scale in recent years, the volume of debt trades like the LBO (Leveraged Buyout) and MBO (Management Buyout) increases. (Gorb, 2017) Leverage and tax benefits increase the value of enterprises, while tax shield represents the difference between the value of a levered and unlevered company. Kemsley and Nissim (2002) estimated the value of interest tax shield at approximately 10 percent of a company's value.

More than fifty years lasting research has brought a number of theories that aim to quantify the value of tax shield as part of company's value. Variations in these approaches are considerable, but most of them focus on the relationship between leverage, capital structure and business value (Nica et. al., 2017; Popp et. al., 2018; Oláh et al., 2017). In addition to tax savings resulting from the leverage, an enterprise should consider other sources of tax shields in financial decision-making, which are called non-debt tax shields (most often it is a depreciation tax shield). The impact of tax savings on decision-making is proportional to its value in the enterprise, thus, each enterprise individually determines the most important types of tax shields for itself (Stonkute, 2018).

The existing theory of the value of tax shield is primarily focused on estimation of the present value of the tax shield and finding the appropriate discount rate, which would take into account both systematic and non-systematic risks in doing business. In addition, most models of the present value of the tax shield have been developed for the Anglo-Saxon economies and developed capital markets (Popescu, 2017; Sadaf et. al., 2018). Several alternative models have already addressed these these shortcomings. Fernandez (2007a) is one of the most famous authors to study this issue. It assumed that the company sets its debt policy on the basis of the target book leverage. Therefore, it is also applicable to emerging markets. The value of debt does not depend on movements at the stock market, thus, it is also suitable for non-listed firms. Credit rating agencies will also focus on book leverage ratio in the process of assigning a certain credit rating. Marciniak (2003) suggested decomposition method for business valuation. In comparison with other models, this method uses the book value of debt and all cash flows discounted at the same discount rate (cost of the unlevered equity rather than the weighted average cost of capital), this prevents the circularity problem. In addition to the already mentioned models, Velez-Pareja (2013) also examined the value of interest tax shield along with the book value of debt. This author found that tax shield is the function of pre-tax profit and interest (Cygler \& Sroka, 2017; Kasych and Vochozka, 2017). 
Overall, the literature provides a wide range of models of the present value of the tax shield in terms of developed markets and, to a lesser extent, also focuses on the application of models in terms of emerging markets. On the other hand, it partially disregards the issue of determinants of the value of tax benefits. It focuses more on the investigation into the determinants of corporate capital structure, because the interest and non-interest tax shields are the factors affecting the capital structure. (Lazaroiu \& Rommer, 2017; Moravcikova et. al., 2017) The value of the tax shield and its determinants is typically analysed and quantified by valuation methods such as discounted cash flow. Unfortunately, this method does not allow us to detect some unknown relationships between variables, such as statistical modelling. Regression modelling was used only in a few studies, as Kemsley and Nissim (2002) and Fama and French (1998), these papers only partially respond to what factors affect the value of the interest tax advantage. In the case of the Slovak Republic, enterprises typically use well known models from the Modigliani and Miller (1963) or Miles and Ezzell (1985), which are adapted to the conditions of emerging markets as referred to, for example, Harumova (2008). Futhermore, the regression modelling is typically used to investigate the determinants of capital structure in the environment of the Slovak Republic (Kalusova, 2015), transitional economies (Delcoure, 2007) or the results of the similar economies are adapted (Strýčková, 2017). From these studies it is possible to estimate the relationship between the level of debt and tax (interest and non-interest) shield, however, prior studies have failed to identify other relationships between the tax benefits and other economic factors in the international context as well as in Slovak enterprises.

For this reason, we consider the use of multiple linear regression to identify statistically significant factors of the interest tax shield primarily in the environment of Slovak enterprises as the novelty of this article.

This research will help to understand better which factors influence the value of interest tax shield and the model could improve decision making in the field of taxation policy.

The aim of the submitted contribution was to propose, quantify and verify a complex model to reveal the determinants of the value of interest tax shield in conditions of the Slovak Republic. The model was developed based on a multiple linear regression analysis, the conditions of multicollinearity of explaining variables, homoscedasticity, autocorrelation and normality of residuals were tested.

Input data were obtained from the financial statements of the year 2017 of more than 6,000 Slovak companies. The study is divided into five parts. The first part Literature review focuses on the previous research of the issue of tax shields, the definition of the tax shield and the views of researchers on the factors influencing the tax shield. Methods and variables used in the models are characterized by Methodology, the chapter also contains formulas to their quantification and interpretation of them. Section three describes the process of research and summarises the results obtained using multiple linear regression, along with testing the assumptions of linear regression model. The obtained findings are also summarized, a model is compared with the existing studies and some other research options of this issue are outlined. Conclusion sum up the results.

\section{LITERATURE REVIEW}

The first impulse for different approaches to quantification of tax shields was the theory of Modigliani and Miller (1958), the authors created the first universally accepted theory of capital structure. The model assumptions show that business value is irrelevant to the capital structure, so it does not matter whether a company is funded by equity or debt. In addition, the model does not assume the existence of taxes. This unrealistic assumption was deleted in the modified model of Modigliani and Miller (1963), abbreviated to MM model; company value increases due to the growth of corporate leverage. This 
newly created value arises from the tax deductibility of interest expense and represents the value of tax shield. Each company could increase its debt due to the growth of company value; however, with leverage growth, the risk of defaults also increases. Leland (1994) created the structural credit risk model, which takes into account the tax deductibility of interest, as well as the costs of financial distress. For this reason, the model is more realistic and permits to optimize and corporate leverage respect to the tax advantage and the credit risk. (Fanelli \& Ryden, 2018; Kyzenko, 2017)

Taking into account the tax system, according to Modigliani and Miller (1963), interest as a tax deductible expense affects the pre-tax profit and hence the amount of tax liability of the company. It follows that even the value of company will change due to the existence of an interest tax shield. The value of tax shield is simply given as a product:

$$
T S=T \cdot R_{D} \cdot D
$$

$T S$ - value of tax shield,

$T$ - corporate tax rate,

$R_{D}$ - cost of debt,

$D$ - market value of debt.

A necessary condition for the creation and application of the tax advantage of debt is positive profit before tax that covers the incurred interest expense.

According to Brealey, Myers and Allen (2010), an interest tax shield is defined as: tax savings resulting from deductibility of interest payments. In Damodaran (2010) the interest tax shield is expressed in a similar vein: Interest is tax-deductible, and the resulting tax savings reduce the cost of borrowing to firms.

In addition to the method of quantification of interest tax advantage in Eq. (1) there are also two different formulations of the value of tax shield. If the debt is constant and perpetual, the company's tax shield depends only on the corporate tax rate and the value of debt. Then the present value of tax shield equals the discounted value of Eq. (1). As the discount factor, the cost of debt $R_{D}$ is used, since the risk of the tax shield (hereinafter TS) should be the same as the risk of interest expenses.

$$
P V(T S)=\frac{T \cdot R_{D} \cdot D}{R_{D}}=T \cdot D,
$$

where $P V(T S)$ is the present value of interest tax shield.

The previous Eq. (1) and (2) show that the tax shield is affected by three variables: corporate tax rate; cost of debt and the value of debt (the market value of debt). Liu (2009), in contrast to the previous formulae, considers tax shield as a variable influenced by four variables: Tax shield is a function of four variables "net income, interest rate, debt, and tax rate." However, the value of the MM tax shields only includes two variables "debt and tax rate," is independent of interest rate, and cannot be true.

Velez-Pareja (2013) defined tax shield similarly to other authors: "Tax shields or tax savings TS, are a subsidy that the Government gives to those who incur in deductible expenses. All deductible expenses are a source of tax savings. This is, labour payments, depreciation, inflation adjustments to equity, rent and any expense if they are deductible."

If it is assumed that the main source of tax savings is interest, the company achieves the tax advantage if earnings before interest and taxes (EBIT) plus other income are sufficient to offset the interest paid by the company. In this case, the value of tax shield is equal to the tax rate multiplied by financial expenses $(F E)$. If the value of EBIT and other income (OI) is less than the amount of financial expenses, the company does not pay corporate income tax. Nevertheless it generates the tax shield; its value is equal to corporate tax rate times EBIT plus other income according to Eq. (3). 


$$
T S=T .(E B I T+O I) \text { if } 0<E B I T+O I<F E
$$

Another possible scenario occurs if the sum of EBIT and OI is negative. Tax savings do not arise because the company does not pay any tax. In sum, all possible cases are given in Eq. (4).

This is significance for further research; most of the literature dealing with the issue of tax shields is based on Eq. (2). It also means that both new businesses and start-ups can achieve partial tax savings, despite the fact that EBIT and $O I$ cannot cover the value of financial expenses. Eq. (4) indicates that the value of tax shield should be a function of EBIT plus $O I$ and not a function of the net income as Liu (2009) argued in his theory.

Calculation of the value of tax shield is not only based on the interest, but in practice it is much more complicated. The deductible expenses for tax calculation also include loss carried forward, deferred tax liability, tax prepayments, etc. If the loss carried forward is allowed, according to Velez-Pareja (2016) the tax shield does not reduce the tax liability in just one period, but its part is transferred to another future period when the loss is carried forward. In simplified terms, the value of tax shield is equal to the formula

$$
T S=\operatorname{Maximum}\left(T \cdot \operatorname{Minimum}\left(E B I T_{a d j}, F E+L C F_{t-1}-L C F_{t}\right), 0\right)
$$

where $L C F_{t-1}$ or $L C F_{t}$ is loss carried forward v time $t(t-1)$.

Other authors are primarily focused on the estimation of an appropriate discount rate for the quantification of the present value of the tax shield. Kaplan and Ruback (1995) assume a firm market value of the debt. They propose to use the cost of unlevered equity as an appropriate discount rate as it indicates the risk of this cash flow. On the other hand, Myers (1974), Ruback (2002) and Luehrman (1997) assume that a debt tax shield is less risky when it meets the assumption mentioned above and is discounted at cost of debt. Miles and Ezzell $(1980,1985)$ and Harris and Pringle (1985) take into account the less strict debt policy, the constant debt-to-equity ratio. According to the authors, the tax shield has a random nature over time and it should be discounted at unlevered cost of equity. Lewellyn and Emery (1986) suggested three different methods for calculating tax shields. In their view, the Miles and Ezzell method is the most consistent and correct. Taggart (1991) summarized the valuation models according to impact on personal taxes and suggested using Miles and Ezzell model if company rebalances debt annually. If the company rebalances debt continuously, then Harris and Pringle model is suitable. Inselbag and Kaufold (1997) recommend using the Myers model if the value of debt is constant; in the case of fixed leverage, the Miles and Ezzell model is suitable. Damodaran (2006) did not mention the formula for the value of tax shield, but Fernandez (2007b) derived, according to the Damodaran equation (30).

Fernandez (2004a) argues that the company debt policy is irrelevant and the value of tax shields is only the difference between the present value of taxes for the unlevered company and the present value for the levered company. Tham and Velez Pareja (2002) agree with the definition, but the claim that it is the same as the definition in the present value of the tax shield (present value of tax shield is simply the tax shield discounting at an appropriate discount rate). Cooper and Nyborg (2006) also argued that Fernandez (2004a) model is based on the combination of two different approaches and the value of tax shield is identical to the Harris and Pringle model in the case of perpetuity. Thus, Fernandez in his studies (2004b) and (2005) modified the original model. He found that the value of tax shield should depend only on the nature of the stochastic process of the net increase of debt and should not depend on the nature of 
the stochastic process of the free cash flow. The issue is to estimate the present value of net increase of debt that requires estimating the appropriate discount rate.

In recent years, the development of the theoretical framework of quantification of tax shields and changes in the economic environment has led to the development of models that include considerably more realistic assumptions than Modigliani and Miller (1963). This is primarily about the assumption of a perfect capital market. Arzac and Glosten (2005), based on the approach of Miles and Ezzell, developed a unique method that eliminates the discount rate. They used ,pricing kernel", a stochastic discount factor. They derived the formula for the company market value, for the market value of equity and for market value of tax shield using an iterative process. Grinblatt a Liu (2008) developed one of the most general approaches to determining the value of tax shield. Their approach is different from all other models, since the Black-Scholes and Merton option models are applied. Couch et al. (2012) linked the value of tax shield and the barrier option, which allowed them to rate the tax shield with a presumption of non-zero risk of default. Molnar and Nyborg (2011) likewise to the previous model used option approach. They extended the framework developed by Cooper and Nyborg (2008) to allow for positive recovery rates.

To sum up, these theories are ambiguous and indicate that the value of tax shield is affected by many quantitative but also qualitative factors.

\section{METHODOLOGY}

In this chapter, we characterize in detail the sample and the methods used in developing the model. Based on the theoretical background, we can consider debt, tax rates and debt (interest rate) as the determinants of the tax shield. On the other hand, this value also affects the company's debt policy, default risk, business profitability and other unknown quantitative and qualitative factors.

The data for this study was obtained from the Amadeus database operated by Burean Van Dijk (BvD) and provides financial information for more than 10 million European companies, including the Slovak Republic. The sampling criteria were in line with the purpose of this paper: the registered office of the company in the Slovak Republic, non-zero pre-tax profit and non-zero interest paid. Those criteria meet the 6,569 businesses. The sample covers the year 2017.

Given the objective of this study interest tax shield was chosen as a dependent variable as the most important source of corporate tax benefits. Its value is quantified by Eq. (1), we use natural log transformation for better data comparability. At the same time, we assume that businesses meet the conditions of existence of a tax shield (non-zero pre-tax profit and positive value of interest paid as a product of a value of debt and cost of debt). The formula for quantification of the explained variable is, as follows

$$
y=I T S=\ln \ln \left(T \cdot R_{D} \cdot D\right)
$$

where ITS is interest tax shield.

The choice of explanatory variables was conditioned by the theoretical framework of this issue as well as by the subsequent study of the determinants of the capital structure, since these two areas of financial management are closely related. We have selected sixteen quantitative variables such as tangibility, liquidity, debt and leverage as well as profitability ratios. In addition, we have selected other indicators that include the impact of growth options, business risks, tax policies, and business size. We also used the cost of debt as an independent variable, quantified by Damodaran (2002) methodology. The algorithms for calculating these variables are shown in Table 1. 
Independent variables and their algorithms

\begin{tabular}{|l|c|l|}
\hline \multicolumn{1}{|c|}{ Variable } & Label & \multicolumn{1}{c|}{ Algorithm } \\
\hline \multicolumn{3}{|c|}{ Tangibility ratios } \\
\hline Fixed assets to total assets ratio & FATA & Fixed assets/total assets \\
\hline \multicolumn{3}{|c|}{ Liquidity ratios } \\
\hline Current ratio & CURR & Current assets/current liabilities \\
\hline Net working capital ratio & NWCA & Net working capital/total assets \\
\hline & Debt and leverage ratios \\
\hline Equity multiplier & EQM & Total assets/Total equity \\
\hline Debt ratio & DEBT & Total liabilities/Total assets \\
\hline Gearing & GEAR & (Non-current liabilities + loans)/equity \\
\hline Interest coverage & INCOV & EBIT/interest paid \\
\hline Debt to EBITDA ratio & DEBTA & Debt/EBITDA \\
\hline \multicolumn{3}{|c|}{ Profitability ratios } \\
\hline Return on assets (gross) & ROA & EBITDA/total assets \\
\hline Return on equity (net) & ROE & EAT/equity \\
\hline \multicolumn{3}{|c|}{ Other ratios and variables } \\
\hline Growth & GROW & (Total assetst-1+ Total assets)/Total assetst-1 \\
\hline Operational risk & RISK & Total sales/EBIT \\
\hline Non debt tax shield & NDTS & Depreciation and amortization/Total assets \\
\hline Cost of debt (tax adjusted) & RD & Riskless rate + default spread of company + rating \\
\hline Effective tax rate & based default spread of country) (1-tax rate) \\
\hline Company size & Taxation/EBT \\
\hline
\end{tabular}

Source: Author's elaboration.

In addition to the quantitative variables, we also decided to use qualitative variables in the model. This is the Industry variable, we used the NACE (SK NACE) categorization to classify enterprises. There are nineteen categories of industry out of twenty-one possible ( $S K N A C E$ categories $A$ to $S$ ) in the sample. We used dummy (binary) variables to indicate the presence or absence of a categorical effect (affiliation to the industry). The number of these variables is $n-1$, where $n$ is the number of industry categories. In total, the model contains 34 explanatory variables; 16 quantitative and 18 dummy variables.

In the first step of analysis we calculated the value of interest tax shield and selected financial ratios and other parameters according to Table 1 and created dummy variables by categories of SK NACE. Because the extreme values of independent variables can falsify the results of the study, we use the Mahalanobis distance to find outliers according to the procedure proposed by Tabachnick and Fidell (2007).

We consider multiple linear regression as the appropriate tool for examining relationships between these variables. There are two types of variables in the model: the explained (dependent) variable and the set of explanatory (independent) variables $\mathrm{x}$. In the resulting model, the dependent variable is a linear combination of independent variables and the intercept, as shown in Eq. (6) (Cipra, 2013).

$$
y_{i}=\beta_{0}+\beta_{1} x_{i 1}+\beta_{2} x_{i 2}+\cdots+\beta_{k} x_{i k}+\varepsilon_{i}
$$

where: 
$y_{i}$ - dependent variable,

$\beta_{0}, \beta_{1}, \beta_{2}, \ldots, \beta_{k^{-}}$unknown parameters of the model,

$x_{i 1}, x_{i 2}, \ldots, x_{i k^{-}}$independent variables,

$\varepsilon_{i}$ - random error (residual) variable.

To provide the multiple linear regression analysis we use the linear regression procedure in $S A S$ Enterprise Guide. We examine the statistical significance of the model as a whole as well as the significance of the regression coefficients. The significance level is 0.05 and those independent variables are significant, whose $\mathrm{p}$-value is less than the significance level. To find relevant and significant variables, we use methods of optimal selection of variables: forward selection, stepwise selection, backward elimination and all possible regressions (Montgomery et al., 2012). After selecting the optimal linear model, the model assumptions are verified; we test assumptions of multicollinearity, homoscedasticity, autocorrelation and normality residues. To eliminate multicollinearity, three statistics are used: Variance inflation factor, Condition index, and Variance proportions. Homoscedasticity is tested by non-specific assays (Goldfeld - Quandt, Bartlett, Levene and Brown-Forsythe test) to determine whether the residues have the same deviation. The other two assumptions are tested by the well-known Durbin-Watson, Kolmogorov-Smirnov, Cramer-von Mises and AndersonDarling tests (Šoltés, 2008). The aim of these tests is to find and verify the model and relevant variables that affect the value of tax shield and improve the financial decision-making of enterprises in the Slovak Republic.

\section{EMPIRICAL RESULTS AND DISCUSSION}

The first step in the modelling process was the calculation of all financial ratios and other indicators in the sample. Subsequently, we analysed the sample; companies with incomplete financial statements were eliminated. Based on the Mahalanobis distance, we identified 205 multivariate outliers. Observations (companies) that contain missing values or are identified as outliers were removed from the sample. Finally, after this procedure, financial indicators of 4,192 Slovak companies were used.

We formed a multiple linear regression model by the least squares method. The natural logarithm of the interest tax shield was explained variable. Independent variables were 16 quantitative and 18 binary variables (SK NACE categories). Table 2 shows regression coefficients, $\mathrm{p}$-values and other statistics.

In the $\operatorname{Pr}>|\mathrm{t}|$ column there are $\mathrm{p}$ - values of $\mathrm{t}$ - tests of significance of regression coefficients. Compared to the chosen level of significance, we reject the null hypothesis (the regression coefficient is statistically significant, $\mathrm{p}=$ alpha). The alternative hypotheses (the non-significance of regression coefficients) are accepted for all dummy variables except binary variables $\mathrm{A}$ and $\mathrm{K}$ (non-significant variables are bold). Non-significant variables should be removed from the model. We do four procedures to remove insignificant variables: forward selection, stepwise selection, backward elimination, and all possible regressions. These methods allow to obtain optimal set of independent variables. 
Linear regression model with all explanatory variables

\begin{tabular}{|c|c|c|c|c|c|}
\hline \multicolumn{6}{|c|}{ Parameter Estimates } \\
\hline Variable & DF & Parameter Estimate & Standard Error & t Value & $\operatorname{Pr}>|t|$ \\
\hline Intercept & 1 & -7.42862 & 0.17819 & -41.69 & $<.0001$ \\
\hline FATA & 1 & 1.04159 & 0.05693 & 18.30 & $<.0001$ \\
\hline CURR & 1 & 0.08931 & 0.01273 & 7.02 & $<.0001$ \\
\hline NWCA & 1 & 0.12385 & 0.04863 & 2.55 & 0.0109 \\
\hline EQM & 1 & -0.00596 & 0.00201 & -2.96 & 0.0031 \\
\hline DEBT & 1 & 0.46563 & 0.08642 & 5.39 & $<.0001$ \\
\hline GEAR & 1 & 0.05024 & 0.00985 & 5.10 & $<.0001$ \\
\hline INCOV & 1 & -0.01172 & 0.00019607 & -59.77 & $<.0001$ \\
\hline DEBTA & 1 & 0.05365 & 0.00607 & 8.84 & $<.0001$ \\
\hline ROA & 1 & 2.47054 & 0.17517 & 14.10 & $<.0001$ \\
\hline $\mathrm{ROE}$ & 1 & -0.25753 & 0.07134 & -3.61 & 0.0003 \\
\hline GROW & 1 & -0.15595 & 0.03258 & -4.79 & $<.0001$ \\
\hline RISK & 1 & -0.01272 & 0.00028024 & -45.38 & $<.0001$ \\
\hline NDTS & 1 & -2.62714 & 0.30417 & -8.64 & $<.0001$ \\
\hline $\mathrm{RD}$ & 1 & 28.66754 & 0.59953 & 47.82 & $<.0001$ \\
\hline ETR & 1 & -0.28559 & 0.05946 & -4.80 & $<.0001$ \\
\hline SIZE & 1 & 0.90927 & 0.00702 & 129.61 & $<.0001$ \\
\hline $\mathbf{A}$ & 1 & 0.32597 & 0.15180 & 2.15 & 0.0318 \\
\hline B & 1 & -0.15522 & 0.20832 & -0.75 & 0.4563 \\
\hline $\mathbf{C}$ & 1 & -0.08948 & 0.14830 & -0.60 & 0.5463 \\
\hline D & 1 & 0.03653 & 0.16512 & 0.22 & 0.8249 \\
\hline $\mathbf{E}$ & 1 & -0.16234 & 0.16477 & -0.99 & 0.3246 \\
\hline $\mathbf{F}$ & 1 & -0.02324 & 0.14998 & -0.15 & 0.8769 \\
\hline G & 1 & -0.14614 & 0.14869 & -0.98 & 0.3257 \\
\hline $\mathbf{H}$ & 1 & -0.01774 & 0.15113 & -0.12 & 0.9065 \\
\hline I & 1 & -0.12331 & 0.15374 & -0.80 & 0.4226 \\
\hline $\mathrm{J}$ & 1 & -0.00232 & 0.15964 & -0.01 & 0.9884 \\
\hline $\mathbf{K}$ & 1 & 0.92724 & 0.28746 & 3.23 & 0.0013 \\
\hline $\mathbf{L}$ & 1 & 0.30080 & 0.16482 & 1.82 & 0.0681 \\
\hline $\mathbf{M}$ & 1 & 0.03061 & 0.15180 & 0.20 & 0.8402 \\
\hline $\mathbf{N}$ & 1 & -0.13786 & 0.15279 & -0.90 & 0.3669 \\
\hline $\mathbf{O}$ & 1 & 0.14806 & 0.41573 & 0.36 & 0.7217 \\
\hline $\mathbf{P}$ & 1 & -0.11023 & 0.22813 & -0.48 & 0.6290 \\
\hline $\mathbf{Q}$ & 1 & 0.12666 & 0.16156 & 0.78 & 0.4331 \\
\hline $\mathbf{R}$ & 1 & -0.08905 & 0.19245 & -0.46 & 0.6436 \\
\hline
\end{tabular}

Source: Author's results.

The decision criterion for selecting a suitable model is Mallows $C p$, a small $C p$ value (less than the number of independent variables of the model) indicates a quality model (Mallows, 1973). Comparison of models by $C p$ is shown in Table 3 .

Table 3

Comparison of Variable Selection Methods by Mallows Cp.

\begin{tabular}{|l|c|c|}
\hline \multicolumn{1}{|c|}{ Variable selection method } & Cp & $\begin{array}{c}\text { Number of var-s in } \\
\text { model }\end{array}$ \\
\hline Forward selection & 23,8013 & 24 \\
\hline Stepwise selection & 23,8013 & 24 \\
\hline Backward elimination & 20,8319 & 25 \\
\hline $\boldsymbol{C}$ selection & 20,8319 & 25 \\
\hline
\end{tabular}

Source: Author's results.

The value of the Mallows' statistics for the Forward and Stepwise selection methods was the same as the $C p$ for the second two methods used. A model with a lower $C p$ value was selected. It contains all 16 
qualitative variables and dummy variables $A, C, E, G, I, K, L, N, Q$. The model was statistically significant according to the results of F-test $(<.0001$ is less than 0.05$)$, and also the variables are significant at the significance level 0.05 .

The next step of the analysis was to verify the assumptions of a linear regression model. First, we verified the presence of multicollinearity in the model. In the case of this model, variables that have a similar interpretation and may be mutually dependent, have been used. Therefore, the variables selected should be removed at the relevant regression model. To find these variables we used the statistics mentioned in the Methodology chapter. There were formed two criteria: if the Variance inflation factor is greater than 10 and / or the Condition index is greater than 30, then the variable is causing multicollinearity and should be removed from the model. In order to meet these criteria, we gradually removed multicollinear variables. As can be seen from Table 4, all qualitative variables cause multicollinearity were removed from the model. This means that the industry as a qualitative mark is not relevant to quantifying the value of interest tax shield; its role is fully held by financial ratios, as their level are typical for a particular sector. Based on the regression parameters, we can deduce that the variables Equity multiplier, Interest coverage, Growth, Operational risk, Non-debt tax shield and Effective tax rate have a negative impact on the value of interest tax shield; on the contrary, the other variables have a positive effect on the dependent variable, as evidenced by the Parameter estimate column in Table 4.

Table 4

Regression coefficients of the final model

\begin{tabular}{|l|c|c|c|c|c|}
\hline \multicolumn{7}{|c|}{ Parameter Estimates } \\
\hline \multicolumn{1}{|c|}{ Variable } & DF & $\begin{array}{c}\text { Parameter } \\
\text { Estimate }\end{array}$ & Standard Error & t Value & Pr $>|\mathbf{t}|$ \\
\hline Intercept & 1 & -7.06317 & 0.07065 & -99.97 & $<.0001$ \\
\hline FATA & 1 & 0.93574 & 0.04403 & 21.25 & $<.0001$ \\
\hline CURR & 1 & 0.05906 & 0.00991 & 5.96 & $<.0001$ \\
\hline EQM & 1 & -0.00591 & 0.00192 & -3.07 & 0.0022 \\
\hline GEAR & 1 & 0.07073 & 0.00857 & 8.26 & $<.0001$ \\
\hline INCOV & 1 & -0.01170 & 0.00019809 & -59.09 & $<.0001$ \\
\hline DEBTA & 1 & 0.05609 & 0.00606 & 9.26 & $<.0001$ \\
\hline ROA & 1 & 1.86812 & 0.12925 & 14.45 & $<.0001$ \\
\hline GROW & 1 & -0.13213 & 0.03260 & -4.05 & $<.0001$ \\
\hline RISK & 1 & -0.01316 & 0.00028089 & -46.84 & $<.0001$ \\
\hline NDTS & 1 & -1.69166 & 0.25822 & -6.55 & $<.0001$ \\
\hline RD & 1 & 29.70723 & 0.59502 & 49.93 & $<.0001$ \\
\hline ETR & 1 & -0.26052 & 0.05921 & -4.40 & $<.0001$ \\
\hline SIZE & 1 & 0.89938 & 0.00682 & 131.95 & $<.0001$ \\
\hline
\end{tabular}

Source: Author's results.

In the last step of the analysis, we tested assumptions about the random error component (residuals) model. The tests mentioned in the previous chapter were used; the results are in Table 5. 
Random error component test results

\begin{tabular}{|c|c|c|c|c|c|c|c|c|}
\hline \multicolumn{8}{|c|}{ Homoscedasticity } & \\
\hline & \multicolumn{7}{|c|}{ Equality of Variances } & \\
\hline & Method & \multicolumn{2}{|c|}{ Num DF } & Den DF & F Value & \multicolumn{2}{|c|}{$\operatorname{Pr}>F$} & \\
\hline & Folded F & \multicolumn{2}{|c|}{2095} & 2095 & 1.52 & \multicolumn{2}{|c|}{$<.0001$} & \\
\hline \multicolumn{9}{|c|}{$\begin{array}{l}\text { Levene's Test for Homogeneity of student_ITS Variance } \\
\text { ANOVA of Squared Deviations from Group Means }\end{array}$} \\
\hline Source & DF & \multicolumn{2}{|c|}{$\begin{array}{l}\text { Sum of } \\
\text { Squares }\end{array}$} & \multicolumn{2}{|c|}{ Mean Square } & \multicolumn{2}{|c|}{ F Value } & $\operatorname{Pr}>F$ \\
\hline Factor & 1 & \multicolumn{2}{|c|}{177.0} & \multicolumn{2}{|c|}{177.0} & \multicolumn{2}{|c|}{42.40} & $<.0001$ \\
\hline Error & 4190 & \multicolumn{2}{|c|}{17497.5} & \multicolumn{2}{|c|}{4.1760} & & & \\
\hline \multicolumn{9}{|c|}{$\begin{array}{c}\text { Brown and Forsythe's Test for Homogeneity of student_ITS Variance } \\
\text { ANOVA of Absolute Deviations from Group Medians }\end{array}$} \\
\hline Source & DF & \multicolumn{2}{|c|}{ Sum of Squares } & \multicolumn{2}{|c|}{ Mean Square } & \multicolumn{2}{|c|}{ F Value } & $\operatorname{Pr}>F$ \\
\hline \multirow{2}{*}{$\frac{\text { Factor }}{\text { Error }}$} & 1 & \multirow{2}{*}{\multicolumn{2}{|c|}{$\frac{20.4927}{1793.0}$}} & \multicolumn{2}{|c|}{20.4927} & \multicolumn{2}{|c|}{47.89} & $<.0001$ \\
\hline & 4190 & & & \multicolumn{2}{|c|}{0.4279} & & & \\
\hline & & \multicolumn{5}{|c|}{$\begin{array}{l}\text { Bartlett's Test for Homogeneity } \\
\text { of student_ITS Variance }\end{array}$} & & \\
\hline & & Source & \begin{tabular}{l|l}
$\mathbf{F}$ & $\mathbf{C h i}$ \\
\end{tabular} & i-Square & $\mathrm{Pr}>\mathrm{Ch}$ & $\overline{h i S q}$ & & \\
\hline & & Factor & & 0.4407 & $<.000$ & & & \\
\hline & & & Autoc & correlation & & & & \\
\hline & & Dur & bin-Wa & atson D & 1.912 & & & \\
\hline & & Numbe & r of $\mathrm{Ob}$ & bservations & 4192 & & & \\
\hline & & 1st Ord & er Auto & ocorrelatior & \begin{tabular}{l|l}
1 & 0.037
\end{tabular} & & & \\
\hline & & & prmality & y of residu & als & & & \\
\hline & & & ests fo & r Normali & & & & \\
\hline & Tes & & & tatistic & & p Val & & \\
\hline Koln & togoror & -Smirnov & $\mathrm{D}$ & 0.043759 & $\operatorname{Pr}>$ & $\mathrm{D}$ & $<0$. & 0100 \\
\hline & mer-vo & n Mises & $\mathrm{W}-\mathrm{Sq}$ & 1.999736 & \begin{tabular}{|l|l|}
$\operatorname{Pr}>V$ \\
\end{tabular} & $\mathrm{~W}-\mathrm{Sq}$ & $<0$. & 0050 \\
\hline & derson- & Darling & $\mathrm{A}-\mathrm{Sq}$ & 12.55695 & \begin{tabular}{l|l} 
& $\operatorname{Pr}>A$ \\
\end{tabular} & $\mathrm{~A}-\mathrm{Sq}$ & $<0$. & 0050 \\
\hline
\end{tabular}

Source: Author's results.

The assumption of equality of variance was tested by four tests; in all cases the null hypothesis of homoscedasticity is rejected and we accept an alternative hypothesis at the significance level of 0.05 . This means that the model parameter estimation is unbiased and consistent, but it is not the best. Estimation of the regression parameter that causes heteroscedasticity is underestimated; however, the estimate of intercept is overestimated. Durbin-Watson test does not show autocorrelation in the model (Durbin - Watson $D$ is higher than $d w_{U}=1.918$ ); this indicates that all relevant variables were included in the model and also linear regression is a suitable regression modelling method. The null hypothesis of normality of residuals was rejected at the significance level of 0.05 . However, the residual normality was significant at the 
significance level of 0.001 in all tests; at the significance level of 0.01 it was significant according to the Kolmogorov-Smirnov test.

Table 6

Results of the final model significance

\begin{tabular}{|l|c|c|c|c|c|}
\hline \multicolumn{7}{|c|}{ Analysis of Variance } \\
\hline Source & DF & Sum of Squares & Mean Square & F Value & Pr $>$ F \\
\hline Model & 13 & 8697.90612 & 669.06970 & 2118.39 & $<.0001$ \\
\hline Error & 4178 & 1319.57172 & 0.31584 & & \\
\hline Corrected Total & 4191 & 10017 & & & \\
\hline
\end{tabular}

Source: Author's results.

At the end of the analysis we tested the significance of the final model (see Table 6$)$. The statistical significance of the model was confirmed at the significance level of $0.05(<.0001<0.05)$. Subsequently, we calculated the determination factor to assess the model's quality. $R^{2}$ has a value of 0.8683 (adjusted $R^{2}$ is 0.8679), indicating that more than $86 \%$ variance in the interest tax shield is predictable from its determinants.

Overall, we have created a model that contains 13 of the quantitative variables; six variables are negatively dependent on the value of the interest tax shield. By contrast, seven variables (Fixed assets to total assets ratio, Current ratio, Debt to EBITD A ratio, Gearing, Return on assets, Tax adjusted cost of debt and Sire) have a positive effect on interest tax advantage. Unlike the traditional models of the interest tax savings mentioned in the Literature review, the model takes into account a more complete set of factors that are necessary to optimize the tax advantage, to increase profitability and to make appropriate financial decisions. Businesses pursue these financial indicators in the framework of its financial policy, but not analysed in the context of the issue of tax shield. The model gives attention to the interrelationships between indicators and extends the debate about the value of the tax shield on the new dimension. Some of our findings are compared with existing results below.

Unlike traditional formulae we have found that the tax shield is influenced not only net (gross) income, interest rate, amount of debt and the tax rate, but also other factors such as collateral (tangibility), companies' ability to meet financial obligations with liquid assets (liquidity), operational risk, etc. This model may be an appropriate tool for financial decision making and enable businesses to better utilize the tax benefit associated with debt.

Our findings are similar to the Velez-Pareja (2013) theory, which found that the tax savings (tax shield) is a function of pre-tax profit and interest. Against the author, we tested the dependency between turnover (SIZE variable) and the interest tax shield. The model indicates that turnover has a significant impact on the tax shield, but there are other variables that determine this value, which has allowed a wider view of the issue. Velez -Pareja (2010a) also identified three sources of risk associated with the risk: the risk of debt in default, the market cost of the debt risk and the operational risk. These factors have been found to significantly affect the interest tax shield in the Slovak Republic as well. Specifically, the default risk is present in current ratio variable as well as in other leverages ratios. The cost of debt risk includes both systematic and non-systematic risk, as the cost of capital consists of the risk-free interest rate (affected by systematic risk) and the default spread (affected by non-systematic risk) (Valaskova and Gregova, 2017). Velez - Pareja (2010a) claims that the tax shield is created by a contractual interest rate and, in the absence of a link between the market and the contractual interest rate, the cost of the debt risk does not affect the contractual cost of the debt. In addition to inflation, which combines these two types of cost of debt, systematic risk is also reflected in fixed interest rates. In contrast to floating interest rates 
they are less risky, but they also include the systemic risk resulting from the sharp rise in fixed rates. This risk is conditioned by current economic conditions.

In terms of capital market expansion, the model is designed for the emerging market. The use of the Modigliani and Miller model (1963) is only appropriate under specific conditions; the Slovak economy does not meet one of the basic conditions of perfect capital markets: the development of capital markets. On the contrary, our model takes into account leverage, like the model Miles and Ezzell (1985), as it is evidenced by the variable Gearing. This financial ratio is an approximation of the Debt to Equity ratio, which is a key factor in the theories Miles and Ezzell (1985), Harris and Pringle (1985), Grinblatt and Liu (2008) or Cooper and Nyborg (2006).

In addition to the above mentioned facts, our regression model examines the relationship between debt tax savings and non-interest tax shields. On the basis of regression coefficients (see Table 4), there is a significant negative relationship between the interest tax shield and the depreciation tax shield. This finding is consistent with the theory of DeAngelo and Masulis (1980), which found that these two tax benefits were offset in order to obtain an optimal tax advantage. On the other hand, Iwin - Garzyńska (2004) argues, a direct relationship between interest rate and depreciation tax was found in the Polish economy. It should be noted that the direction of the regression coefficient in the multiple model may differ from the direction of the correlation coefficient. DeAngelo and Masulis (1980)hypothesis can be accepted only if the other factors examined are taken into account. The individual relationship between variables has not been investigated and can be part of further research.

This model is unique because the value of the tax shield is not typically modelled by regression, unlike the issue of capital structure. Only some partial results can be cross compared. For example, Feld, Heckemeyer and Overesch (2011) investigated 46 studies in order to provide a quantitative overview of the impact of taxation on capital structure. Their findings suggest that the capital structure choices are indeed positively affected by the tax, i.e., there exists a positive significant relationship between these variables. Mokhova and Zinecker (2013) review capital structure in the European Union countries. They concluded their study, claiming that the non-debt tax shield can have a positive or negative impact on leverage (capital structure) with regard to the fact that the theory of capital structure is preferred. The maturity of the debt also greatly affects the strength and significance of the relationship between the determinants (Vinczeova \& Kascakova (2017) have focused on the financial decisions of Czech small and medium sized enterprises. They evidenced that half of Slovakian SMEs set the target debt ratio and one of the most important factors affecting capital structure is cost of capital. Tax shield is a key element of the cost of capital, which is also confirmed by our conclusions.

This study has some limitations given by the choice of statistical methods and variables. We have used multiple linear regressions to determine the significant factors of interest tax shield. This method is subject to the strict assumptions we tested. Rejected autocorrelation indicates that we have included relevant variables in the model and the functional form of the model is correct. On the contrary heteroscedasticity of the model says that the estimate of regression coefficients is not a BLUE estimate. Nevertheless, the method is significant for determining the relevant tax shield determinants. To remove heteroscedasticity and to improve the explanatory power transformation of a variable, e.g. Box - Cox transformation, should be used.

Microeconomic factors (financial ratios) were used as independent variables. In addition, personal taxing may be used in future research, for example, Miller (1977), Taggart (1991) or Pareja-Velez (2017). The study can be extended to other countries and a longer time period. Panel data model also makes it possible to include macroeconomic factors similarly as in models of capital structure (see Booth et al., 2001; Bas et al., 2010; Overesch \& Voeller, 2010 or Jibran et al., 2012). 


\section{CONCLUSION}

Nowadays, almost every company finances its activities by equity and debt. In general, equity is considered to be more expensive and more risky because, unlike creditors' income (interest paid), dividends do not give the enterprise any advantage. The tax deductibility of interest is called tax shield and its management is part of the financial (tax) policy of the company. It affects as much net income the company and the value of the company. The issue of tax shields mainly aims to estimate an appropriate discount rate, to a lesser extent, to investigate the factors that influence this value.

Hence, the main objective of this study was to create an econometric model (multiple regression model) to reveal relevant and significant determinants of the value of interest tax shield. The model was quantified using financial information of 6,569 Slovak enterprises, of which 34 explanatory variables, 16 quantitative and 18 binary variables were calculated. In the next step, a linear regression model was created using the variable selection methods and the appropriate model was selected. Subsequent assumptions of the model were tested and the optimal model was found. The final regression model did not contain binary variables; the industry has no significant impact on the value of tax shield. Significant determinants include 13 quantitative variables: fixed assets to total assets ratio, current ratio, equity multiplier, gearing, interest coverage, debt to EBITD A ratio, gross retirement, asset tax, of debt, effective tax rate and company size. The following factors may be considered to be relevant and their management can greatly help to optimize the value of interest tax shield. Based on the coefficient of determination it can be considered a regression model quality, more than $86 \%$ of the variance interest tax shield is predictable from the above financial indicators. These results evidenced that companies should take into account not only cost of debt, value of debt and corporate tax rate, but also other quantitative determinants (financial indicators). Knowledge of these relationships can significantly improve the quality of decision making of enterprises and increase their profitability.

Nevertheless research provides many other areas that have not been explored. There are other methods of exploration such as Monte Carlo simulation (Velez - Pareja, 2010b) or the production function of the enterprise (Menichini, 2017).

In conclusion this paper contributes to fill the gap in the field of determination the factors of tax shield.

\section{ACKNOWLEDGEMENT}

The paper is an output of the science project VEGA 1/0428/17 Creation of New Paradigms of Financial Management At The Threshold of The 21stcentury In Conditions Of the Slovak Republic.

\section{REFERENCES}

Arzac, R.A., \& Glosten, L.R. (2005). A reconsideration of tax shield valuation. European Financial Management, 11(4), 453-461. doi: 10.1111/j.1354-7798.2005.00292.x.

Bas, T., Muradoglu, G., \& Phylaktis, K. (2010). Determinants of Capital Structure in Developing Countries. In: Proceedings of European Financial Management Symposium 2010, Asian Finance. Beijing: Renmin university of China. Retrieved from http://www.efmaefm.org/0EFMSYMPOSIUM/2010-China/papers/determinants $\% 20$ of $\% 20$ capital $\% 20$ structure $\% 20$ in $\% 20$ developing $\% 20$ countries.pdf.

Batchimeg, B. (2017). Financial Performance Determinants of Organizations: The Case of Mongolian Companies. Journal of Competitiveness, 9(3), 22-33. doi:10.7441/joc.2017.03.02

Booth, L., Aizavian, V., Demirguc - Kunt, A., \& Maksimovic, V. (2001). Capital structure in developing countries. Journal of Finance, 56(1), 87-130. doi: 10.1111/0022-1082.00320.

Brealey R.A, Myers, S.C, \& Allen, F. (2010). Principles of Corporate Finance. 10 ${ }^{\text {th }}$ ed. New York: McGraw-Hill/Irwin.

Cipra, T. (2013). Finanćni ekonometrie. $2^{\text {nd }}$ ed. Praha: Ekopress. 
Cooper, I.A., \& Nyborg K.G. (2006). The value of tax shields IS equal to the present value of tax shields. Journal of Financial Economics, 81(1), 215-225. doi: 10.1016/j.jfineco.2005.07.003.

Cooper, I.A., \& Nyborg, K.G. (2008). Tax-adjusted Discount Rates with investor Taxes and Risky Debt. Financial management, 37(2), 365-379. doi: 10.1111/j.1755-053X.2008.00016.x.

Couch, R., Dothan, M., \& Wu., W. (2012). Interest tax shields: A barrier Option Approach. Review of quantitative finance and accounting, 39(1), 123-146. doi: 10.1007/s11156-012-0282-3.

Cygler, J; Sroka, W. (2017). Coopetition Disadvantages: the Case of the High Tech Companies. Inqinerine EkonomikaEngineering Economics, 28(5), 494-504.

Damodaran A. (2010). Applied Corporate Finance. $3^{\text {rd }}$ ed. New York: John Wiley \& Sons.

Damodaran, A. (2002). Investment Valuation: Tools and Technique for Determining the Value of Any Assets. $2^{\text {nd }} \mathrm{ed}$. New York: John Wiley \& Sons.

Damodaran, A. (2006). Damodaran on Valuation: Security Analysis for Investment and Corporate Finance. $2^{\text {nd }}$ ed. New York: Wiley.

DeAngelo, H., \& Masulis, R.W. (1980). Optimal capital structure under corporate and personal taxation. Journal of financial economics, 8(1), 3-27. doi: 10.1016/0304-405X(80)90019-7.

Delcoure, N. (2007). The determinants of capital structure in transitional economies. International Review of Economics and Finance, 16, 400-415.doi: 10.1016/j.iref.2005.03.005.

Fama, E.F., \& French, K.R. (1998). Taxes, Financing Decisions and Firm Value. The Jornal of Finance, 53(3), 819-843. doi: 10.1111/0022-1082.00036.

Fanelli, V.; Ryden, A.K. (2018). Pricing a Swing Contract in a Gas Sale Company, Economics, Management, and Financial Markets, 13(2), 40-55.

Feld, L.P., Heckemeyer, J. H., \& Overesch, M. (2011). Capital structure choice and company taxation: A meta-study, ZEW Discussion Papers, No. 11-075, Zentrum für Europäische Wirtschaftsforschung (ZEW), Mannheim. Retrieved September 09, 2018, from: https://www.econstor.eu/handle/10419/54979

Fernandez, P. (2004a). The value of tax shield is NOT equal to the present value of tax shields. Journal of Financial Economics, 73, 145-165. doi: 10.1016/j.jfineco.2002.10.001.

Fernandez, P. (2004b). The value of tax shields and the risk of the net increase of debt (Working Paper No. 544). Available at SSRN: https://ssrn.com/abstract $=506005$.

Fernandez, P. (2005). The value of tax shields is not equal to the present value of tax shields: A correction. (Working Paper No. 581). Available at SSRN: https://ssrn.com/abstract $=651206$.

Fernandez, P. (2007a). A more realistic valuation: Adjusted Present Value and WACC with constant book leverage ratio. Journal of Applied Finance, 17(2), 13-20. doi: http://dx.doi.org/10.2139/ssrn.946090.

Fernandez, P. (2007b). Valuing companies by cash flow discounting: ten methods and nine theories. Managerial Finance, 33(11), 853-876. doi:10.1108/03074350710823827.

Gorb, O. (2017). Development of complex approach to defining the notion "sustainable development of rural territories. Forum Scientiae Oeconomia, 5(2), 87-99.

Grinblatt, M, \& Liu J. (2008). Debt policy, corporate taxes, and discount rates. Journal of Economic Theory, 141(1), 225254. doi:10.3386/w9353.

Harris, R.S., \& Pringle, J.J. (1985). Risk-adjusted discount rates - extensions from the average-risk case. The Journal of Financial Research, 8(3), 237-244. doi:10.1111/j.1475-6803.1985.tb00406.x.

Harumova, A. (2008). Stanovenie bodnoty majetku: blavné aspekty ekonomickej znnaleckej a expertnej činnosti. Bratislava: Iura Edition.

Inselbag, I., \& Kaufhold, H. (1997). Two DCF approaches for valuing companies under alternative financing strategies (and how to choose between them). Journal of applied corporate finance, 10(1), 114-122. doi:10.1111/j.1745-6622.1997.tb00132.x.

Iwin-Garzyńska, J. (2004). Empirical Verification of Depreciation Tax Shield Theory in Conditions of Polish Economy in Transformation. Ekonomia, 15, 25-34.

Jibran, S., Wajid, S.A., Waheed, I., \& Muhammad, T. (2012). Pecking at Pecking Order Theory: Evidence from Pakistan's Non-financial Sector. Journal of Competitiveness, 4(4), 86-95. doi: 10.7441/joc.2012.04.06.

Kalusova, L. (2015). Skúmanie odvetvových diferencií medzi faktormi determinujúcimi finančnú štruktúru slovenských a českých podnikov. Ekonomický časopis, 63(10), 1033-1052.

Kaplan, S.N., \& Ruback, R.S. (1995). The Valuation of Cash Flow Forecasts: An Empirical Analysis. Journal of Finance, 50(4), 1059-1093. doi: 10.2307/2329344.

Kasych, A., \& Vochozka, M. (2017). Theoretical and methodical principles of managing enterprise sustainable development, Marketing and Management of Innovations, 2, 298-305.

Kemsley, D., \& Nissim, D. (2002). Valuation of the debt tax shield. Journal of Finance, 42(5), 2045-2074. doi:10.1111/0022-1082.00488. 
Ključnikov, A., Kozubíková, L., \& Sopková, G. (2017). The Payment Discipline of Small and Medium-sized Enterprises. Journal of Competitiveness, 9(2), 45-61. doi:10.7441/joc.2017.02.04

Kyzenko, O., Hrebeshkova, O., \& Grebeshkov, O. (2017), Business intelligence in the economic management of organization, Forum Scientiae Oeconomia, 5(2), 15-27.

Lazaroiu, G., \& Rommer, D. (2017). Digital technologies, labor markets, and economic reputation, Ekonomickomanazerske spektrum, 11(2), 13-21.

Leland, H.E. (1994). Corporate debt value, bond covenants, and optimal capital structure. Journal of Finance, 49(4). 1213-1252. doi. https://doi.org/10.1111/j.1540-6261.1994.tb02452.x.

Lewellen, W.G., \& Emery, R.E. (1986). Corporate debt management and the value of the firm. Journal of Financial and Quantitative Analysis, 21(4), 415-426. doi: 10.2307/2330689.

Liu, Y. (2009). The slicing approach to valuing tax shields. Journal of Banking \& Finance, 33, 1069-1078.

Luehrman, T.A. (1997). Using APV: A better tool for valuing operations. Harvard business review, 75, 145-154.

Mallows, C.L. (1973). Some Comments on Cp. Technometrics, 15(4), 661-675. doi: 10.1080/00401706.1973.10489103.

Marciniak, Z. (2003). Wykorazystanie zróżnicowanych stóp kosz̨u kapitalu do wyceny przedsiębiorstw i oceny projektów inwestycyjnych. In: Z. Szyjewskij, J.K. Grabara, J. Nowak (Ed.). Proceedings of Efektywność zastosowań systemów informatycznych 2003. Warszawa: Wydawnictwa Naukowo-Techniczne.

Menichini, A.A. (2017). On the value and determinants of the interest tax shields. Review of Quantitative Finance and Accounting, 48(3), 725-748. doi: 10.1007/s11156-016-0566-0.

Miles, J.A, \& Ezzell, J.R. (1980). The weighted average cost of capital, perfect capital markets, and project life: A clarification. Journal of Financial and Quantitative Analysis, 15(3), 719-730.doi: 10.2307/2330405.

Miles, J.A., \& Ezzell, J.R. (1985). Reformulating tax shield valuation: A note. Journal of Finance, 40, 1485-1492. doi: 10.1111/j.1540-6261.1985.tb02396.x.

Miller, M.H. (1977). Debt and Taxes. Journal of Finance, 32(2), 261-275. doi: 10.1111/j.1540-6261.1977.tb03267.x.

Modigliani F., \& Miller M.H. (1963). Corporate income taxes and the cost of capital. A correction. The American Economic Review, 53(3), 433-443.

Modigliani, F., \& Miller, M.H. (1958). The Cost of Capital, Corporation Finance and the Theory of Investment. The American Economic Review, 48(3), 261-297.

Mokhova, N., \& Zinecker, M. (2013). The determinants of capital structure: the evidence from the European Union. ACTA UNIVERSITATIS AGRICULTURAE ET SILVICULTURAE MENDELIANAE BRUNENSIS. LXI(7), 2533-2546. doi: 10.11118/actaun201361072533.

Molnar, P., \& Nyborg, K.G. (2011). Tax-adjusted Discount Rates: a General Formula under Constant Leverage Ratios. European Financial Management, 19(3), 1-10. doi: 10.1111/j.1468-036X.2011.00619.x.

Montgomery, D.C., Peck, E.A., \& Vining, G.G. (2012). Introduction to Linear Regression Analysis. $5^{\text {th }}$ ed. New York: John Wiley \& Sons.

Moravcikova, D., Krizanova, A., Kliestikova, J., \& Rypakova, M. (2017). Green marketing as the source of the competitive advantage of the business. Sustainability, 9(12), art.no. 2218.

Myers, S.C. (1974). Interactions of corporate financing and investment decisions - Implications for capital budgeting. Journal of Finance, 29(1), 1-25. doi: 10.1111/j.1540-6261.1974.tb00021.x.

Nica, E., Comanescu, M., \& Manole, C. (2017). Digital Reputation and Economic Trust in the Knowledge Labor Market. Journal of Self-Governance and Management Economics, 5(3), 83-88.

Oláh, J., Karmazin, Gy., Máté, D., Grabara, J. K., Popp, J. (2017). The effect of acquisition moves on income, pretax profits and future strategy of logistics firms. Journal of International Studies, 10(4), 233-245. doi: 10.14254/2071-8330.2017/10-4/18

Overesch, M., \& Voeller, D. (2010). The Impact of Personal and Corporate Taxation on Capital Structure Choices. FinanzArchiv/Public Finance Analysis, 66(3). 263-294.

Paseková, M., Svitáková, B., Kramná, E., Otrusinová, M., Kolářová, E., \& Crhová, Z. (2018). Problematic Areas of Accounting: Some Evidence from the Czech Republic. Journal of Competitiveness, 10(1), 89-105. DOI: 10.7441/joc.2018.01.06

Popescu L. D. (2017). Global Policy Mechanisms, Intergovernmental Power Politics, and Democratic DecisionMaking Modes of Transnational Public Administration. Geopolitics, History, and International Relations, 9(2), 199205.

Popp, J., Kot, S., Lakner, Z., \& Olah J. (2018). Biofuel use: Peculiarities and implications, Journal of Security and Sustainability Issues, 7(3), 477-493.

Ruback, R.S. (2002). Capital cash flows: A simple approach to valuing risky cash flows. Financial Management, 31(2), 85-103. doi: $10.2139 /$ ssrn.223080.

Sadaf, R., Olah, J., Popp, J., \& Mate, D. (2018). An investigation of the influence of the worldwide governance and competitiveness on accounting fraud cases: A cross-country perspective. Sustainability, 10: ar. no: 588.

Šoltés, E. (2008). Regresná a korelačná analýza s aplikáciami. Bratislava: Iura Edition. 
Strouhal, J., Štamfestová, P., Ključnikov, A., \& Vincúrová, Z. (2018). Different Approaches to the EBIT Construction and Their Impact on Corporate Financial Performance Based on the Return on Assets: Some Evidence from Czech TOP 100 Companies. Journal of Competitiveness, 10(1), 144-154. doi:10.7441/joc.2018.01.09

Stonkute, E., Vveinhardt, J., \& Sroka, W. (2018). Training the CSR Sensitive Mind-Set: The Integration of CSR into the Training of Business Administration Professionals. Sustainability, 10(3), art. no. 754.

Strýčková, L. (2017). The Relationship Between Company Returns and Leverage Depending on the Business Sector: Empirical Evidence from the Czech Republic. Journal of Competitiveness, 9(3), 98-110. doi:10.7441/joc.2017.03.07.

Šimková, N. (2015). The Hierarchical Clustering of Tax Burden in the EU27. Journal of Competitiveness, 7(3), 95-109. DOI: $10.7441 /$ joc.2015.03.07

Tabachnick, B.G., \& Fidell, L.S. (2006). Using Multivariate Statistics. $5^{\text {th }}$ ed. Boston: Pearson.

Taggart, R.A. (1991). Consistent valuation and cost of capital: Expressions with corporate and personal taxes. Financial Management, 20, 8-20. doi: 10.2307/3665747.

Tham, J, \& Velez-Pareja I. (2002). Much Ado about Nothing: A Non-technical Comment on the Present Value of The tax Shield (PVTS). (Working Paper no. 23). Available at SSRN: https://ssrn.com/abstract=345660.

Valaskova, K., \& Gregova, E. (2017). Modelling of costs of capital in Slovak enterprises. Ekonomicko-manazerske spektrum, 11(2), 76-89.

Velez - Pareja, I. (2013). Return to Basics: Are You Properly Calculating Tax Shields? Análisis Financiero, 122. 6-17.

Velez-Pareja, I. (2010a). Risky Tax Shields: An Exploratory Study. Cuadernos de Administración, 23(41), 213-235.

Velez-Pareja, I. (2010b). Risky Tax Shields and Risky Debt: A Monte Carlo Approach. Retrieved July 16, 2018, from https://ssrn.com/abstract $=1630056$.

Velez-Pareja, I. (2016). Tax shield, financial expenses and losses carried forward. Cuadernos de Economics, 35(69), 663689. doi: 10.15446/cuad.econ.v35n69.54352.

Velez-Pareja, I. (2017). Do Personal Taxes Destroy Tax Shields? A Critique to Miller's (1977) Proposal. Emerging Markets Finance and Trade, 53(10), 2199-2214. doi: 10.1080/1540496X.2016.1220859.

Vinczeova, M., Kascakova, A. (2017). How do Slovak small and medium-sized enterprises make decision on sources of finance? Ekonomicko-manazerske spektrum, 11(2), 111-121. 